\title{
Miten aikuisten perustaidot määritellään?
}

\section{Perustaidot PIAAC-tutkimuksesta paikalliseen diskurssiin}

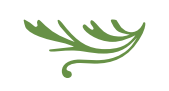

Taloudellisen yhteistyön ja kehityksen järjestö OECD tulkitsee, mitkä ovat kansalaisten perustaidot ja mittaa niitä kansainvälisellä aikuistutkimuksella. Tulkinnoillaan ja tutkimustuloksillaan se ohjaa kansallisen koulutuspolitiikan retoriikkaa, mikä edelleen suuntaa koulutuksen toteuttajia. Tulkinta on yksipuolinen, jos ei oteta huomioon paikallista tasoa eivätkä eri tasot ole dialogissa.

\section{$\mathbf{y}$}

TRKI KATAISEN (KOK.) HALLITUS asetti ta-

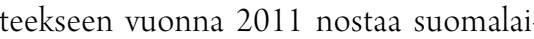
maailman osaavimmaksi kansaksi vuoteen 2020 mennessä (OKM 2014). Opetus- ja kulttuuriministeriön hallinnoiman valtakunnallisen Taito-ohjelman (2014-2020) tavoite on vahvistaa osaamista erityisesti niillä aikuisilla, joilla on heikot perustaidot. Ohjelman vahva taustavaikutin on taloudellisen yhteistyön ja kehityksen järjestön OECD:n (Organisation for Economic Cooperation and Development) teettämä kansainvälinen aikuistutkimus (PIAAC, The Program for the International Assessment of Adult Competencies), joka usein rinnastetaan peruskoululaisten taitoja mittaavaan PISA-tutkimukseen. Tutkimusta johti yhdysvaltalainen Educational Testing Service, ja se toteutettiin kansainvälisten tutkimusorganisaatioiden yhteistyöllä. PIAAC-aikuistutkimus toteutettiin ensi vaiheessaan (2011-2012) 24 maassa, ja toiseen vaiheeseen (2014-2015) osallistui yhdeksän uutt maata ${ }^{1}$. PIAAC-tutkimuksen maaraportin mukaan Suomessakin on merkittävä joukko aikuisia, joilla on niin heikot perustaidot, että se haittaa heidän arkeaan.

Perustaidot eivät ole suora suomennos tutkimuk sen käyttämistä termeistä. PIAAC-tutkimuksess
MIK ̈̈̈̈N KANSAINVÄLINEN

ORGANISAATIO EI OLE

VAIKUTTANUT LÄNTISTEN

TEOLLISUUSMAIDEN

KOULUTUSPOLITIIKKAAN YHT

PALJON KUIN OECD.

käytetään samassa merkityksessä termejä aikuisten taidot, adult skills ja avaintaidot, key competencies (OECD 2013). Suomen osuudessa käytössä on kuitenkin termi foundation skills, joka näyttäisi viittaavan käytettävään perustaidot-suomennokseen. PIAACtutkimuksessa perustaidot määritellään luku-, numero- ja ongelmanratkaisutaidoiksi teknologisest kehittyneissä ympäristöissä (literacy, numeracy and problem solving in technology-rich environments). Lukutaidoilla tarkoitetaan kirjoitettujen tekstien ymmärtämistä ja käyttämistä tavoitteiden saavuttamiseksi sekä tiedon ja valmiuksien kehittämiseksi. Numerotaidoilla viitataan kykyihin hankkia, käyttää, tulkita ja viestiä matemaattista tietoa ja ajattelua. Ongelmanratkaisutaidot teknologisesti kehittyneissä ympäristöissä määritellään kyvyiksi ratkaista työtä ja elämää koskevia tilanteita hyödyntämällä digitaalisia viestintävälineitä ja tietoverkkoja. (OECD 2012.) Tutkimus sisältää maakohtaisia suosituksia, jotka Suomen tapauksessa kohdistuvat erityisesti niihin, joilla on heikot perustaidot (OECD 2015; Musset 2015).

OECD:n rooli koulutuspoliittisen keskustelun sekä tutkimus- ja kehitystyön suuntaajana on merkittävä. Mikään muu kansainvälinen organisaatio ei ole vaikuttanut läntisten teollisuusmaiden koulutuspolitiikkaan samassa määrin kuin $\mathrm{OECD}$, vaikka se ei ole tehnyt mitään oikeudellisesti jäsenmaitaan velvoittavia päätöksiä (Rinne ym. 2004, 456; Kopecký 2011). Sen ohjausvalta perustuu tiedonhallintaan, jota se toteuttaa esimerkiksi perustaitoja mittaavill ja maita vertailevilla arviointitutkimuksilla.

OECD:n kasvanut rooli kansainvälisessä tutkimus- ja kehitystyössä on herättänyt kritiikkiä, jok ei kuitenkaan juuri näy julkisessa keskustelussa. Globalisoituva koulutuspolitiikka ja ylikansallisen asiantuntijapuheen vaikutukset kansallisella tasolla herättävät kysymyksiä. Tutkijat ovat esimerkiksi pohtineet OECD:n roolia koulutuksen suuntaamisessa ja sen valtaa nimetä ja määritellä ihmisten tarvitsemat perustaidot. Kriittinen keskustelu kohdistuu yhtä lailla järjestön asemaan kansallisten päättäjien, kuten ministeriöiden virkamiesten, ylikansallisena neuvonantajana kuin muutosten tai poliittisten ratkaisujen oikeutukseen sen tutkimusten pohjalta.

PIAAC-tutkimuksen asiantuntijapuheen vaikutus perustaitojen määrittelyyn on ilmeinen, ja sen tulkinta kansalaisten tarvitsemista perustaidoista ohjaa selvästi monien maiden koulutuspolitiikan retoriikkaa. Kansalaisten tarvitsemien perustaitojen määrittely ja koulutuspoliittinen ohjaaminen kansallisella tasolla vaikuttaa ulkoistetulta ylikansallisille toimijoille. (esim. Grek 2009, 34; Rinne ym. 2004. )

Esimerkiksi Taito-ohjelman tavoittelema osaava kansalaisuus on määritelty yksinomaan tämän kansainvälisen aikuistutkimuksen esittämän kasvatuspuheen ja mittariston perusteella. Euroopan sosiaalirahaston (ESR) rahoitusta kanavoidaan Taitoohjelman kautta organisatorisille ja pedagogisille toimijoille, eli järjestöille ja koulutusorganisaatioille, jotka etsivät ratkaisuja viiteryhmiensä taitojen kehittämiseen. Kasvatustehtävä maailman osaavimmaks kansaksi osoitetaan näin toimijoille, joilla on ruohonjuuritason pedagogista asiantuntemusta.

Tutkimukseni käynnisti Taito-ohjelman lähilukeminen, joka herätti kysymyksiä ohjelman sanoman perusteista ja vaikutuksista suomalaiseen aikuiskoulutukseen. Sanoma perustuu PIAAC-selvitykseen, ja siitä puuttuvat paikalliset asiantuntijoiden ja toimijoden näkemykset. Ohjelman välittämä asiantuntijapuhe on kuitenkin toistaiseksi välittynyt valtajulkisuuteen perustaidoista lähes sellaisenaan ilman muita argumentaatioita.

Pohdin tutkimuksessani tapoja, joilla perustaidoista puhutaan ja merkityksiä tai sosiaalisen todellisuuden versioita edistetään ja pyrin lisäämään taitopuheen moniäänisyyttä. Puheella viittaan sekä suullisiin että kirjallisiin esityksiin, joita nimitän 'taidoista käytäväksi diskurssiksi'. Teen diskurssissa paljastuvi 
TUTKIMUKSEN KÄYNNISTI

TAITO-OHJELMAN

LÄHILUKEMINEN.

valtasuhteita näkyviksi ja kyseenalaistan yksipuolistavia tulkintoja. Globalisoituvan koulutuspolitiikan rinnalla tuon esiin kontekstuaalisia ja erilaisissa tulkintakehyksissä syntyviä puheenvuoroja. Haen vastauksia seuraaviin kysymyksiin: Miten perustaidot puheen eri tasoilla ja konteksteissa määritellään? Miten eri tasojen diskurssit heijastuvat toisiinsa? Miten yhteistä ymmärrystä perustaidoista rakennetaan?

Pohdin PIAAC-tutkimuksen diskurssin siirtymistä kansallisen tason ohjelmapuheeseen ja ohjelmallisen retoriikan heijastumista toiminnalliselle tasolle.

Empiirisinä aineistoinani ovat Taito-ohjelman dokumentit ja PIAAC-tutkimus, jota tarkastelen erityisesti Suomen osalta. Toiminnallisen tason diskurssin aineistona ovat Taito-ohjelman hankkeiden ja niiden kohderyhmän teemahaastattelut. Diskurssissa huomioni kiinnittyy erityisesti aikuisten perustaitojen määrittelyyn, puutteellisten taitojen kuvaamiseen ja taitojen kehittämisehdotuksiin.

En pyri tulkitsemaan PIAAC-tutkimuksen tuloksia tai perustaitojen hallintaa sellaisenaan, vaan perustaidoista käytävää argumentointia ja retoriikkaa, jotka ovat esillä käsittelemässäni aineistossa. Mielenkiintoni kohdistuu diskurssiin ja siihen, mitä sillä tehdään. Nostan esiin näkemyksiä koulutuksen ammattilaisilta ja niistä aikuisten kohderyhmistä, joita asia koskettaa.

Vaihtoehtoisena yhteiskunnallisen kehittämisen mallina esitän yhteistoiminnallisen viestintämallin, jossa ongelmia pikemminkin esitetään ja pohditaan kuin yksisuuntaisesti ratkaistaan

Tutkimukseni rakentuu perustaitodiskurssin eri tasojen analysoinnille. Koska PIAAC-tutkimuksen perustaitosanoma maakohtaisine suosituksineen on osoitettu kansallisen koulutuksen kehittäjille, etenen analyysissa sanoman lähettäjästä seuraavan tason vastaanottajaan eli kansainvälisestä asiantuntijapuheesta kansalliselle ja paikalliselle tasolle. Nimitän kansainvälistä asiantuntijapuhetta makrotason diskurssiksi, Taito-ohjelman sisältöä mesotason diskurssiksi ja paikallisten toimijoiden keskusteluja mikrotason diskurssiksi (Lester ym. 2016; van Dijk 1993).

Ensimmäiseksi käsittelen PIAAC-tutkimuksen tarjoamaa asiantuntijapuhetta ja sen kriittisiä koh tia. Toiseksi tarkastelen tämän diskurssin vaikutust kansalliseen ohjelmapuheeseen: miten kansainvälinen puhe näkyy kansallisella tasolla? Kolmanneks analysoin retoriikan mahdollista leviämistä hanketoimijoiden ja niiden kohderyhmien eli mikrotason keskusteluun perustaidoista. Pohjustan tutkimusta taustoittamalla aiheen tutkimuskenttää.

\section{PERUSTAITOJEN TUTKIMUS}

TIETOYHTEISKUNNASSA

Keskustelua kansalaisten perustaidoista on käyty en aikoina eri nimillä ja eri merkityksissä. 1960-1980-luvun retoriikan pääpaino oli yhteiskuntakehityksen edistämisessä mutta myös yksilöille suotuisan, tasaarvoa tukevan kehityksen tukemisessa esimerkiks kohentamalla luku- ja laskutaitoja ja käytännön taitoja (Rinne 2004). 1990-luvun lopun ja 2000-luvun alkupuolen yhteiskuntapoliittisissa keskusteluiss keskeisiksi nousi teknologiavetoisen tietoyhteiskunnan haasteisiin vastaaminen. Puhe tietoyhteiskuntavalmiuksista levisi 2000-luvulla tutkimus- ja kehitystyöhön. Euroopan unioni johti eurooppalaista kehityskulkua tietoyhteiskuntaan siirtymistä valmistavilla ohjelmilla, joissa sosiaaliset ja taloudelliset ulottuvuudet yhdistettiin hallinnon, terveyden ja koulutuksen alueilla (Rantala \& Suoranta 2008, 99).

Euroopan unionin kilpailukyvyn kehittämiseks laaditussa Lissabonin strategiassa (2000) kansalaisten perustaidoiksi määriteltiin informaatioteknologian käyttötaidot, vieraat kielet, teknologinen kulttuuri yritteliäisyys ja sosiaaliset taidot (European Parliament 2000). Tällöin muotoutui näkemys eurooppalaisesta koulutusmallista, jonka ytimessä olivat tieto ja elinikäinen oppiminen. Elinikäisen oppimisen konseptista tuli selkeä osa aikuisia koskevaa koulutuspolitiikkaa (Kopecký 2011). Samaan aikaan alkoivat sähköiseen kansalaisuuteen eli e-kansalaisuuteen valmentavat kansalliset ja paikalliset ohjelmat ja niitä seuraavat toiminnalliset ja pedagogiset kehittämishankkeet.

Aikuisten tarvitsemia kognitiivisia perustaitoja on tarkasteltu viestinnän tutkimuksessa esimerkiksi kansalaisen roolia koskevien puhetapojen kautta. Markkinatalouden ja julkishallinnon puhetavoissa kansalaisten tarvitsemat taidot painottuvat kuluttamisen ja asiakas-käyttäjä-roolin mahdollistumiseen, kun taas kansalaisyhteiskunnan retoriikassa keskeisiä ovat erityisesti vaikuttavan osallistumisen taidot (Delanty 2000).

Mediakasvatuksen näkökulmasta vuorovaikutus ja aktiivinen toiminta korostuvat, jolloin riittävään taidolliseen kompetenssiin kuuluvat sekä vastaanottoon että erityisesti viestin tuottamiseen kuuluvat taido (Kupiainen 2006). Aikuiskasvatustieteessä puhe perustaidoista on usein kytkeytynyt keskusteluun elinikäisestä oppimisesta, joka on esiintynyt toistuvana teemana myös OECD:n tutkimuksissa (esim. Tuomisto 2004). Pedagoginen näkökulma on puolestaan merkinnyt huomion kiinnittämistä aikuiskoulutuksen keinoihin edistää tarvittavien taitojen oppimista.

Aikuisten perustaitoja koskevat tutkimukset ja hankkeet viittaavat yhä useammin Euroopan unionin ja OECD.n rahoittamiin, hallinnoimiin tai tukemiin ohjelmiin. OECD:n teettämät kansainväliset tutkimukset, kuten PISA, TALIS, PIAAC ja AHELO, ovat nousseet viime vuosikymmeninä keskeisiksi koulutuspolitiikkaan vaikuttajiksi. PISA-tutkimuksessa on selvitetty koululaisten taitoja, TALIS on opetuksen ja oppimisen tutkimus ja AHELO on korkeakouluopiskelijoiden oppimistulosten arviointitutkimus.

OECD:n merkittävään rooliin tiedonhallinnassa vaikuttavat sen mittavat resurssit ja jäsenmaiden tuki. Tutkimustuloksia käytetään jatkotutkimusten aineistoina, ja järjestön käyttämät osaamista mittaavat indikaattorit, kategorisointi ja inhimillisen paäoman käsite ovat monien tutkimusten osana. Esimerkiksi saksalaisissa kasvatusalan artikkeleissa viittaukset OECD:n tutkimuksiin ovat lähes kahdeksankertaistuneet vähemmässä kuin kymmeness̈ vuodessa (Cort \& Larson 2015, 532). PIAACtutkimusta on hyödynnetty maakohtaisissa tutki muksissa ja selvityksissä esimerkiksi perustaitojen merkityksestä yhteiskuntaan ja työelämään osallis tumisessa.

Samalla tutkijoiden kriittiset näkemykset globalisoituvaa koulutuspolitiikkaa kohtaan ovat lisääntyneet (esim. Griffin 1998; Rinne 2004; Antikainen 2006). 1990-luvun lopulla OECD:n suosima elinikäisen oppimisen retoriikka ja siihen kytkeytyva uusliberalistinen ajattelu ovat olleet kriittisen keskustelun kohteina (Griffin 1998; Kopecký 2011). Kasvatustieteilijä Risto Rinteen mukaan leimallist uusliberalistisen koulutuspolitiikan etenemisessä Suomessa on ollut äänettömyys, hiljaisuus, ristiridattomuus ja pienet askeleet (Rinne 2004, 222).

Rinne analysoi vuonna 2004 hallitusohjelmaa jonka retoriikassa välittyi Euroopan unionin ja OECD.n diskurssi sekä kansalaisten lisääntynyt oma vastuu tietoyhteiskunnassa menestymisessä. Suom on hänen mukaansa ollut liiankin innokas mukautumaan OECD:n koulutuspolitiikkaan (Rinne ym. 2004). Puhe perustaidoista jatkaa elinikäisen oppimisen retoriikkaa, jossa oppimisesta on tullut koulutusta keskeisempää ja valtiosta enemmän strategi kuin politiikantekijä (Griffin 1998). Jotkut tutkijat suhtautuvat kriittisesti OECD:n edelleen kasvaneeseen kognitiivisen ja normatiivisen johtoasemaan kansainvälisessä tutkimus- ja kehitystyössä (esim. Morgan \& Volante 2016; Yasukawa \& Black 2016; Windemeersch \& Olesen 2012). Jotkut kasvatustieteilijät ovat pyrkineet laajentamaan keskustelua ja kehottaneet nostamaan esiin paikallista asiantuntemusta sek muita tutkimuksia koulutuksen kehittämisessä (Sle \& Stambach 2010; Tsatsaroni \& Evans 2013)

Suomea koskevan PIAAC-tutkimuksen toteuttivat OECD:n ohjeistamana Jyväskylän yliopiston Koulutuksen tutkimuslaitos ja Tilastokeskus, ja sen rahoittivat opetus- ja kulttuuriministeriö sekä työ-j elinkeinoministeriö. Useat elinikäistä oppimista käsittelevät tutkijat ovat käyttäneet maaraporttia osana lähdeaineistoaan.

Suomessa PIAAC-tutkimuksesta julkisuuteen ovat erityisesti nousseet tulokset, jotka osoittavat, ett 600000 suomalaisella on heikot perustaidot (esim. HS 2015; Lyly-Yriänäinen 2015). Tämä PIAAC-tutkimuksen maaraportissa nähty huolenaihe on johtanut muutamiin ristiriitaisiin tilannetulkintoihin. 
Kritttinen KeskUSTELU

KANSAINVÄLISEN

ASIANTUNTIJAPUHEEN

VAIKUTUKSISTA ON OLLUT

SUOMESSA VÄH ̈̈IST $\ddot{\text { Ä. }}$

Turun yliopiston koulutussosiologian tutkijoiden mukaan maaraportista julkisuuteen ja ohjelmapolitiikkaan nostetut arviot siitä, että isolla joukolla suomalaisia on heikot taidot, ovat metodologisen väärinymmärryksen tulosta (Kivinen ym. 2016). Vastakkaisena näkökulmana he tuovat esiin taloustieteilijöiden Eric Hanushekin ja Ludger Woessmannin tutkimuksen (2015), joka PIAAC-tutkimukseen nojaten arvioi Suomen nousevan tietoyhteiskuntakehityksen kärkimaaksi. Laajempi keskustelu on kuitenkin toistaiseksi vähäistä, eivätkä vaihtoehtoiset perustaidoista tehdyt selvitykset ole juuri päässeet PIAAC-tutkimuksen täydentäjiksi tai kilpailijoiksi kansallisen koulutuksen ja tutkimuksen kehittämisessä. Kriittinen keskustelu kansainvälisen asiantuntijapuheen vaikutuksista on jäänyt Suomessa marginaaliseksi.

Tähänastinen, joskin vähäinen PIAAC-selvityksen kriittinen tarkastelu on keskittynyt tutkimuksen menetelmiin ja tulosten relevanssiin. Tarkastelen perustaitoja eri diskurssien kautta ottamatta kantaa keskusteluun PIAAC-tutkimuksen tuloksista, kuten heikkotaitoisten suomalaisten lukumäärästä. Diskursseja analysoimalla avaan kriittistä keskustelua perustaidoista eri tulkintakehyksien valossa, jolloin mikä tahansa ymmärrys perustaidoista voi olla yhtä hyvä kuin jokin toinen.

Tutkimuksessani yhdistyvät aikuiskasvatustieteen elinikäisen oppimisen ja viestintätieteiden vaikuttavan osallistumisen tutkimusalueet, joissa vastaavaa perustaitojen diskurssianalyysia ei ole aiemmin toteutettu. Se jatkaa kriittistä keskustelua globalisoituvasta koulutuspolitiikasta kuitenkin välttäen vastakkainasettelua ja rakentaen monitulkintaisempaa ymmärrystä aikuisten perustaidoista analysoimalla niistä käytävää diskurssia eri tulkintakehyksissä. Esitän uutta tietoa tuomalla diskurssin tasoja ja niihin kytkeytyviä valtasuhteita näkyviksi.

\section{AINEISTO JA MENETELMÄT}

Tarkastelen puhetta perustaidoista yhteiskuntapoliittisella ja toiminnallisella tasolla sekä näiden välisess vuorovaikutuksessa. Yhteiskuntapoliittisen puheen aineistona ovat Taito-ohjelman dokumentit sekä sitä tukevat PIAAC-tutkimuksen tutkimusraportit ja suositukset Suomelle. Toiminnallisen tason aineisto koostuu Taito-ohjelman hanketoimijoiden sekä niiden kohderyhmään kuuluvien aikuisten puolistruk turoiduista teemahaastatteluista.

Tutkimusaineisto valittiin selvittämään perustaitodiskurssin heijastumista OECD-tasolta ohjelmalliselle ja toiminnalliselle tasolle sekä tuomaan esiin toimijatason puhetta ja ymmärrystä. Aineisto koottiin loka-marraskuussa 2017 ja tammikuussa 2018 kolmessa ryhmähaastattelussa, joissa oli 16 osallistujaa. Ensimmäiseen osallistui Taito-ohjelman hankkeiden vastuuhenkilöit (7), toiseen nuoria 18-23-vuotiaita aikuisia (5) ja kolmanteen noin 50-vuotiaita aikuisopiskelijoita (4).

Hanketoimijat tunsivat PIAAC-tutkimuksen pääpiirteittäin, mutta kohderyhmät eivät yleensä olleet kuulleet tutkimuksesta. Haastateltavia pyydettiin kuvailemaan arkielämän tärkeimpiä perustaitoja. Hanketoimijat osallistuivat haastatteluun pedagogisin ammattilaisina, eli perustaitoja tarkasteltiin aikuiskouluttajan viitekehyksessä. Nuoret ja aikuisopiskelijat saivat kertoa ja keskustella perustaidoista oman kokemuksensa perusteella.

Tutkimuksen keskeisiä menetelmiä ovat lähiluku ja diskurssianalyysi, joita olen toteuttanut analysoimalla PIAAC-tutkimuksen ja Taito-ohjelmapuheen tekstiä sekä perustaitotematiikan etenemistä koskevaa responsiivista puhetta eli sitä, miten eri osapuolet tulkitsevat toistensa puheenvuoroja ja sitä kautta rakentavat tulkintaansa sosiaalisesta todellisuudest (Jokinen ym. 2002, 127). Teemahaastattelujen puheet äänitettiin ja litteroitiin analysointia varten. Diskurssianalyysilla pyrin hahmottamaan erilaisia ymmärtämisen tapoja ja merkitysten heijastumista tutkimusaineiston eri tasoilla makrotasolta mikrotasolle.
Viestinnän vuorovaikutteisuuden tulkitsemisessa käytän viestinnän tutkija Jan Servaesin poliittista päätöksentekoa ja kansalaisten osallistumista koskevaa viestinnän teoriaa. Viestintä voi hänen mukaansa toimia mekanistisen tai yhteistoiminnallisen eli orgaanisen mallin mukaisesti. Mekanistinen malli merkitsee auktoriteettien, kuten poliitikkojen ja asiantuntijoiden, määräämää työskentelyä. Yhteistoiminnallinen malli on luonteeltaan osallistuvaa ja yhteistä ymmär rystä tavoittelevaa. (Servaes 1999, 194. .)

PIAAC-tutkimuksen ja Taito-ohjelman tarkasteluissa olen käyttänyt apuna politiikan tutkija Caro Bacchin poliittisen retoriikan analysointiin kehittämäa What's the problem represented to be - eli WPR-menetelmää. Diskurssianalyysin kohteena on erityisesti poliittisen ohjelman sisältämän ongelman representaatio el tapa, jolla ongelma esitetään ja se, millaisia mielikuvia ongelmasta luodaan

WPR-menetelmässä ohjelmaa luetaan keskittymällä siihen, miten ongelma esitetään, mistä se on peräisin ja millaisia mielikuvia siitä luodaan. Tutkimuskohdetta voidaan tarkastella vain eri näkökulmista merkityksellistettyinä tulkintoina, ei objektiivisen faktana. (Bacchi 2009.) Olennaista on vuorovaikutuksen vaikutus sosiaalisen todellisuuden rakentumiseen ja valtasuhteiden vaikutus asioiden merkityksellistämiseen

WPR-menetelmässä tutkittavaa diskurssia tarkastellaan kuuden kysymyksen avulla: 1) mikä on se ongelma, joka esitetään ja johon haetaan ratkaisua 2) mitä ennakko-oletuksia ongelman esittämisen taustalla on, 3) miten tietty ongelman representaatio on muodostunut, 4) mitä jätetään sanomatta ja problematisoimatta, 5) mitä vaikutuksia ongelman representaatiolla tuotetaan ja 6) miten tietty ongelman representaatio saavuttaa hallitsevan aseman ja miten se voidaan kyseenalaistaa tai esittää sille vaihtoehtoja. (Bacchi 2009; 2012.) Taito-ohjelman tapauksessa kysymyskehikko auttaa kiinnittämään huomiota poliittisen retoriikan tuottamaan ongelman representaatioon, sen alkuperään, oletuksiin ja puuttuviin näkökulmiin.

Diskurssianalyysin tukena sovellan kehysteoriaa. Sen mukaan vuorovaikutus tapahtuu aina jossain merkitysjärjestelmässä, kehyksessä, jota ilman tilannetta ei voida ymmärtää. Kehystäminen on joidenkin puolien valitsemista havaitusta todellisuudesta ja niiden esittimistä vuorovaikutustilanteissa. (Karvonen 2000,79, Entman 1993, 52.) Tässä tutkimuksessa on olennaista tehdä huomioita toimijoiden tulkintakehyksistä arvottamatta niitä. Tutkimuksessa ovat näkyvissä asiantuntijoiden, poliitikkojen, aikuiskouluttajien sekä haastateltujen nuorten aikuisten ja keski-ikäisten kehystämät diskurssit.

Vaikka tavoitteeni ei ollut lähestyä tutkimuskohdetta kriittisesti vaan enemmänkin analyyttisesti, aineisto tuotti kriittistä potentiaalia sisältäviä tuloksia. Tuloksena ei tällöin ole vallitsevan sosiaalisen todellisuuden rakentaminen vaan myös sen kyseenalaistaminen ja purkaminen. Keskeisinä ovat vallan määrittämät diskurssit ja niiden tuottamien totuuksien purkaminen (van Dijk 1993, 253; Jokinen ym. 2002 , $85-89$.)

Olen kuitenkin pyrkinyt olemaan avoin aineistolle ja välttämään oletuksia asioiden luonteesta. Analyysia voi siten nimittää sekä analyyttiseksi että kriittiseksi: analyyttinen diskurssianalyysi sisältää perustaidoista käytävän puheen tarkastelun sosiaalisen todellisuuden rakentumisena, kriittinen näkökulma taas mahdollistaa asioiden representaatioiden purkamisen ja uusintamisen. Lopuksi pohdin hallitsevan representaation vaikutuksia ja esitän vaihtoehtoisia kuvauksia perustaidoista.

Tutkijan positioni on lähtökohtaisesti Taito-ohjelmaan sitoutunut ja sikäli tulkittavissa ohjelman asianajajaksi. Tavoitteeni on kuitenkin asettua positioon, jossa tarkastelen puhetta muuhun keskusteluun reflektoiden ja etsien siihen uusia tulokulmia.

Pyrin välittämään havaintojani molempiin suuntiin: Ohjelmallisen retoriikan sisältämiä oletuksi kyseenalaistamalla voin tehdä tilaa vaihtoehtoisille ja kuulematta jääneille puheenvuoroille. Samalla voin tukea koulutuspolitiikan kehittämistä selvittämällä ohjelmasanoman vastaanottoa sekä taitoja koskevaa keskustelua ohjelman kohderyhmissä. Koska diskurssit syntyvät erilaisissa tulkintakehyksissä, en arvioi esimerkiksi asiantuntijakehystä sellaisenaan, vaan tavoitteeni on lisätä tulkintakehyksissä syntyvien näkökulmien välistä ymmärrystä ja vuorovaikutusta. 


\section{PIAAC-DISKURSSISSA}

HYVINVOINTI JA TAIDOT

KYTKETÄÄN TOISIINSA.

\section{PERUSTAIDOT PIAAC-TUTKIMUKSEN} ASIANTUNTIJAPUHEESSA

Perustaidot on kehystetty PIAAC-tutkimuksen asiantuntijadiskurssissa vahvasti menestymiseen globaalissa taloudessa. Perustaidot ovat "globaaleja taitoja" (OECD 2013, 105), eikä yleismaailmallista kontekstia problematisoida, mikä saattaa johtaa perusteettomiin yleistyksiin. Tutkimuksen tarjoama retoriikka on tyyliltään konsensukseen suostuttelevaa ja yksinkertaistavaa (OECD 2012; OECD 2013). PIAAC-tutkimuksen mukaan valtioiden tulisi mitata aikuisväestönsä taidot selvittääkseen, miten hyvin ne ovat valmistautuneet modernin tietoyhteiskunnan haasteisiin (OECD 2015).

PIAAC-tutkimuksen Suomen-tilannearviossa todetaan, että osaamisen taso vaihtelee eri väestöryhmissä, ja Suomessakin on merkittävä joukko aikuisia, joiden perustaidot ovat riittämättömät nopeast muuttuvassa kilpailutaloudessa menestymiseksi (M lin ym. 2012, 84; OECD 2015). WPR-analyysimallia soveltaen diskurssin esittämänä ongelmana näyttäytyvät ne aikuiset, joilla on heikot perustaidot (Bacchi 2009). Maaraportin diskurssissa perustaidoiltaan he kot kategorisoidaan esimerkiksi määreillä 'syrïäytymisen riskiryhmät' tai 'ongelmia hyvinvoinnissa' (Mali ym. 2012, 78-81)

Osaamisen jakaminen väestöryhmiin vaikutta PIAAC-tutkimuksen perusteella hankalalta, mutt jossain määrin maaraportissa riskiryhminä näyttäytyvät maahanmuuttajat, ikääntyvät ja ilman koulutusta olevat nuoret (OECD 2015), joille valtiolliset ohjelmat voidaan suunnata (Hamilton 2016,10).

PIAAC-diskurssi sisältää ennakko-oletuksen hyvinvoinnin ja taitojen kytkeytymisestä toisiinsa. Tätä perustellaan inhimillisen pääoman (human capital) diskurssilla, jota on käytetty yleisesti OECD:n kognitiivisia taitoja koskevien tutkimusten teoreettisen johtolankana. Inhimillinen pääoma on määritelty "tiedoiksi, taidoiksi, kompetenssiksi ja ominaisuuksiksi, jotka ovat oleellisia yksilöiden taloudellisess toiminnassa" (OECD 1998, 9; OECD 2013,100).

OECD:n kansallisiin ohjelmiin tarjoama koulutuspolitiikka ehdottaa perustaitojen kohentamista keinoksi menestyä globaalitalouden kilpailussa (OECD 2015, 84). Representaatio perustuu aiempiin OECD:n tutkimuksiin ja osallistujamaissa toteutettuihin mittauksiin. PIAAC-tutkimuksen mukaan se on kyennyt mittaamaan kolmea inhimillist päöomaa tuottavaa kognitiivista taitoa: lukutaitoa numerotaitoa ja ongelmanratkaisutaitoa teknologisesti kehittyneissä ympäristöissä. Lisäksi pääomaa voivat tuottaa esimerkiksi henkilökohtaiset ominaisuudet (OECD 2013, 19-33).

Bacchin WPR-analyysimallia seuraten inhimillisen pääoman diskurssissa jäävät sanomatta ja problematisoimatta muut taloudelliseen hyvinvointiin sisätyvät tekijät, kuten valtion talouspolitiikka, teollisuusja työllisyyspolitiikka, sijoittaminen ja luonnonvarat. Oletus on tällöin, että työmarkkinat toimivat ilman häiriötekijöitä (Morgan \& Volante 2016).

PIAAC-tutkimuksessa tuodaan esiin muuttuvan ja epävarman maailmantalouden vaikutukset perustaitovaatimuksiin, mutta ei mainita globalisaation vaikutuksia esimerkiksi lukemisen ja viestinnän käytäntöihin. PIAAC-tutkimuksen asiantuntijadiskurss ei myöskään esitä kansallisten erityispiirteiden tai sosiokulttuuristen tilanteiden näkökulmia.

OECD:n perustaitoja koskevaa diskurssia vois kuvata diffuusio-mekanistisen viestinnän tyyppiseksi. Viestinnällisessä diffuusiossa sanoma levitetään asiantuntijoiden makrotasolta toiminnalliselle mikrotasolle. Samalla tapahtuu kulttuurista diffuusiota, eli teknologiset ja kulttuuriset ilmiöt leviävät ja yhdenmukaistuvat. Mekanistinen viestintä merkitse ylhäältä alas suuntautuvaa puhetta ja retoriikkaa, jolla pyritään ongelmien ratkaisemiseen sekä valmiiksi tarjottuihin päämääriin

Servaesin määrittelemä mekanistinen politiikan teon malli kuvaa auktoriteettien määräämä työskentelyä, oppimista ja tiedonkulkua, mikä on suoraviivaisuudessaan helpoiten toteutettava ja tuloksia painottava (Servaes 1999, 195). PIAAC tutkimuksen perustaitodiskurssissa on mekanistisen mallin piirteitä, mutta puhe on retorisest konsensukseen suostuttelevaa. Se sisältää oletuksia yleismaailmallisista haasteista, kuten digitalisoitumisesta ja työelämän muutoksista, sekä niihin parhaiten sopivista ratkaisuista, esimerkiksi aikuiskoulutuksesta. Ratkaisu pyritään ohjaamaan retorisesti yhteiseen päämäärään esimerkiksi käyttämällä kontrastipareja, kuten huiput - heikot, toistoa sekä menestymiseen ja osallistamiseen viittaavaa puhet ta, mikä luo vaikutelmaa demokraattisesta yhteisen hyvän rakentamisesta. (OECD 2015.)

PIAAC-tutkimuksen sisältämä oletetun ongelman representaatio vaikuttaa selvästi aikuiskoulutuksen linjauksiin niin Suomessa kuin kansainvälisesti, mikä näkyy esimerkiksi Taito-ohjelman diskurssissa. PIAAC-tutkimuksessa inhimillisen pääoman yhdistäminen koulutuksen tavoitteeksi voidaan nähdä pehmeäksi säätelyksi globalisoituvassa koulutuspolitiikassa.

Diskurssilla luodaan tehokkaasti käsitystä todellisuudesta, jonka kyseenalaistaminen vaikuttaa haastavalta tai jopa turhalta. PIAAC-tutkimuksen representaatio vaikuttaa saavuttaneen hallitsevan aseman perustaitojen määrittelijänä ilman vaihtoehtoja. Samalla kun diskurssi ja sen sisältämä tulkintakehikko (Entman 1993, 52) mahdollistavat asioiden näkemisen tietyllä tavalla, ne rajoittavat muita näkemisen tapoja.

\section{PERUSTAIDOT KANSALLISEN OHJELMAN} OHJAAVASSA DISKURSSISSA

Taito-ohjelma kuuluu kansalaisten osaamista kehittävään hallitusohjelmaan. Sen retoriikassa ovat mukana näin sekä hallituksen määrittämä intress että kansainvälinen taloudellis-poliittisten liittojen välittämä diskurssi. Ohjelman sanoma suunnataan erityisesti toimijataholle, koulutusorganisaatioille a aikuiskouluttajille, joilta odotetaan keinoja ongelman ratkaisemiseksi. Hallitus näyttäytyy siten enemmän strategian luojana luopuessaan politiikantekijän roolistaan (Griffin 1998, 446).
Kansallisen ohjelman määrittämiä koulutuksellisia tavoitteita toteutetaan mobilisoimalla aktiivisia toimijoita (Edwards 2002, 353). Samalla voidaan puhua aikuisopiskelun markkinoista, jolloin hallitus säilyttää valvovan roolinsa, mutta vastuu siirtyy yksilöille, joille organisaatiot markkinoivat tukeaan (Rinne 2004).

Poliittiset ohjelmat sisältävät yleensä suoran tai epäsuoran representaation oletetusta ongelmasta. WPR-lähestymistavassa poliittista ohjelmaa luetaan kohdistamalla huomio erityisesti ongelman representaatioon. Bacchin mukaan poliittiset ohjelmat yleensä perustuvat oletuksiin ongelmista, jotka ohjelmilla pyritään ratkaisemaan. Monesti ongelmia ei kuitenkaan täsmällisesti määritellä. Ongelman esityksestä riippuu, mitä pitäisi korjata, eli huomiota ei pitäisi keskittää ainoastaan ongelman ratkaisemiseen vaan sen asetteluun ja löytämiseen. (Bacchi 2009.) WPR-lähestymistavan mukaisesti Taito-ohjelman diskurssin tarkastelussa kiinnitetään huomio esitetyn ongelman representaatioon, sen alkuperään, sen luomiin mielikuviin sekä mahdollisesti puuttuviin näkökulmiin.

Taito-ohjelmassa kuvataan, kuinka "lukutaito, numerotaidot sekä tieto- ja viestintätekniikkataidot ovat nyky-yhteiskunnan perustaitoja, jotka ovat edellytys täysipainoiselle työelämään osallistumiselle" (OKM 2014, 7). Ongelmana esitetään perustaitojen heikkous osalla väestöstä: "PIAAC toi esiin sen, että Suomessakin on merkittävä joukko myös työssäkäyviä aikuisia, joilla perustaidot ovat heikot" (OKM 2014, 7). Taito-ohjelman diskurssissa välillisenä ongelmana näyttäytyy myös koulutuksen puute. Oletus ongelmasta perustuu yksin PIAAC-tutkimukseen.

Representaatio kehystetään PIAAC-tutkimuksesta tuttujen nyky-yhteiskunnan, elinikäisen oppimisen ja muutoksiin sopeutumisen käsitteillä. Näin luodaan mielikuvaa globaalitalouden haasteisesta kontekstista, jossa selviämiseksi on kilpailtava uuden teknologian välinein: "Suomi voi kilpailla globaaleilla markkinoilla ainoastaan vahvalla osaamisella luovuudella ja hyödyntämällä uusia sosiaalisia ja teknologisia innovaatioita” (OKM 2014, 5). 
KANSALLISEN OHJELMAN

DISKURSSISSA OLETUS

ONGELMASTA PERUSTUU

\section{PIAAC-TUTKIMUKSEEN.}

Ongelman representaatio sisältää ajatuksen talouden arvaamattomuudesta, johon on sopeuduttava, eli retorisesti tilanne konstruoidaan faktaksi ja sitä tarkastellaan työmarkkinanäkökulmasta. Ohjelman tavoite on "vähentää heikon taitotason omaavien aikuisten osuutta väestöstä merkittävästi vuoteen 2020 mennessä" (OKM 2014, 7), mikä viittaa myös Eurooppa 2020 -strategian mukaiseen kansalliseen toimeenpano-ohjelmaan. Tavoitteet ovat näin yhtenevät sekä OECD:n että Euroopan unionin diskurssin kanssa.

Tavoitteen saavuttamiseksi "tarvitaan toimia, joilla luodaan kohderyhmälähtöisesti spesifejä toimintamalleja aikuisten perustaitojen kehittämiseen ja vakiinnutetaan ne" (OKM 2014, 7). Tavoite on muotoiltu passiiviksi, eli varsinainen tekijä puuttuu. Sanoman aktualisointi on kuitenkin selvästi ulkoistettu aikuiskoulutuksen kehittäjille ja toteuttajille, jotka voivat hakea taitojen kehittämiseen ESR-rahoitusta.

Bacchin mukaan hallitukset yleensä aktivoituvat korjaamaan identifioituja ongelmia, jotka ovat poliittisten prosessien ulkopuolella (Bacchi 2009). Tämä on tyypillistä nykyisessä uusliberalistisessa koulutuspolitiikassa, jossa valtio suljetaan koulutuksen kentällä pääpelaajan paikalta ja kentälle päästetään markkinavoimat ja muut toimijat (Rinne 2004; Edwards 2010). Ohjelmassa ongelman ratkaiseminen ohjataan toimijatasolle, joka on lähempänä kohderyhmiä. Diskurssin kohteena ja PIAAC-tutkimuksen osoittamana ongelmana ovat aikuiset, joilla on heikot taidot ja joita pyritään kannustamaan kompetenssinsa lisäämiseen.
Taito-ohjelman argumentaatio "osallisuuden edistämisen tavoite eriarvoisuuden ja syrjäytymisen ehkäisemiseksi” on konsensusta rakentavaa. Samalla jäävät kertomatta osallisuuden ja syrjäytymisen erilaiset merkitykset yhteiskunnassa ja ihmisten kokemusmaailmassa. Kohderyhmien näkökulmat eivät ole mukana diskurssissa, tai niihin viitataan abstraktisti:"[--] vaikeudet ovat epäilemättä tulleet vastaan" (OKM 2014, 7). Ohjelman diskurssi luo mielikuvaa tasa-arvoisuuden lisäämisestä, mutta viestinnällä kohderyhmät asemoidaan sopeutuvaan positioon. Paikalliset kohderyhmät eivät tässä diskurssissa osallistu ongelman märittelyyn, koska määrittely on tehty kansainvälisellä tasolla. Kohderyhmien oletetaan kuitenkin pyrkivän perustaitojensa kohentamiseen, vaikka opiskelu saa diskurssin valossa enemmän velvollisuuden kuin oikeuden merkityksiä. Eriarvoisuuden ehkäisemisen tavoite antaa ensisijaisesti vaikutelman emansipaatiosta, mutta näyttää samalla sisältävän tavoitteen kansalaisten talouselämän vaatimuksiin integroimisesta.

Retorisesti diskurssi toimii vaihtoehdottomuuspuheena, jossa faktat ikään kuin puhuvat puolestaan (Jokinen 2002,140). Diskurssissa ei ole muita näkökantoja tai vasta-argumentteja. Perustaitojen määritelmä ja taitojen puutteet Suomessa todistetaan oikeiksi PIAAC-tutkimuksella, joka edustaa luotettavaa argumentin esittäjä. Ohjelmapuheeseen ei tuoda muita tutkimuksia eikä näkökantoja kansalaisten tarvitsemista perustaidoista.

PIAAC-tutkimukseen perustuen poliittisella ohjelmalla luodaan tietty ymmärrys ongelmasta, mikä vaikuttaa siihen, miten toimitaan. Bacchin mukaan näin mikä tahansa totuus on yhtä hyvä kuin jokin toinen (Bacchi 2012), ja kannanotot valittuun totuuteen nähden vaikuttavat herkästi turhilta. WPRmenetelmän mukaisesti voidaan kysyä, mitä vaikutuksia kyseisellä ongelman representaatiolla tuotetaan. Voidaan myös ajatella, että ilman ongelman representaatiota ongelma lakkaa olemasta. Sellaisina niitä aletaan käsitellä vasta, kun ne jostakin näkökulmasta katsottuna määritellään niin haitallisiksi, että tulkinta asian ratkaisemisen tarpeellisuudesta vahvistuu (Juhila 2002, 167).
PERUSTAIDOT AIKUISKOULUTTAJIEN JA AIKUISOPISKELIJOIDEN TULKINTAKEHYKSISSA

Taito-ohjelman viesti suunnataan erityisesti organisaatioiden ja järjestöjen edustajille, jotka voiva edistää aikuisten perustaitoja kehityshankkeilla. Hankkeen toteuttaminen tarjoaa organisaatioille rahoitusta uusien toimintamallien kehittämiseksi ja käytännöiksi juurruttamiseksi.

Analysoin seuraavaksi haastateltujen hankkeiden edustajien (7) sekä aikuisopiskelijoiden (9) puhetta perustaitojen määrittelyn, taitojen heikkouksien ja esitettyjen ratkaisujen näkökulmista, ja vertaan sitä ohjelmalliseen diskurssiin.

Taito-ohjelman hanketoimijat työskentelevät oppilaitoksissa ja järjestöissä hankevastaavina ja ovat aikuiskoulutuksen ammattilaisia. Hankkeiden kohderyhmiin kuuluvat esimerkiksi maahanmuut tajat, erityistukea tarvitsevat opiskelijat ja yleisest aikuiset, joiden kognitiiviset taidot ovat riittämättömiä arkielämän haasteisiin. PIAAC-tutkimuksen suosituksiin verrattuna hankkeet määrittelevät kohderyhmänsä kuitenkin laajemmin ja kohdistavat toimintansa yleensä organisaation asiakaskuntaan, kuten aikuisopiskelijoihin.

Taito-hankkeiden julkisessa diskurssissa, esimerkiksi hankkeiden esittelyteksteissä, välittyy ohjelman ja PIAAC-tutkimuksen tarjoama perustaitoretoriikka. WPR-analyysin mukaan tarkasteltuna poliittisen retoriikan esittämä ongelman representaatio vaikuttaa hankesuunnitelmiin, jotka on laadittu vastaamaan ohjelmahakuun.

Perustaitojen ja niiden heikkouksien määrittely on siirtynyt PIAAC-diskurssista Taito-ohjelman kautta ohjelman toteuttajille, joille on osoitettu ohjelmarahoituksen kautta ongelman ratkaisijan rooli. Hanketoimijat puhuvat kuitenkin perustaidoista useimmiten työssä tehtyjen havaintojen näkökulmasta, eikä ohjelmallinen taitoretoriikka juuri välity heidän diskurssissaan. Taito-ohjelman ja hanketoimijoiden esittämä ongelman representaatio on samansuuntainen, mutta toimijatasolla sen käsittely syvenee. Perustaidoista ja niiden heikkouksista puhutaan osin eri ter meillä, ja ne liitetään vaihteleviin elämäntilanteisiin Hanketoimijoiden diskurssi kytkeytyy ammatilliseen ja institutionaaliseen positioon. Se avaa tulkintakehyksenä erilaisia näkökulmia perustaitoihin, joita voidaan pitää vaihtoehtoisina tai laajempina ongelman representaatioina (Bacchi 2009).

Hanketason diskurssi on sävyltään empaattista ja kohderyhmien tilanteisiin asettuvaa. Hanketoimijat kertovat taitojen puutteista monien elämää ja opiskelua rajoittavana ongelmana, johon uusia toimintamalleja kaivataan. Keskeisinä ovat kohderyhmillä havaitut tarpeet ja organisaation mahdollisuudet vastata niihin.

Työelämän ja opiskelun haasteita kuvaillaan passiivimuodoin väistämättömiltä vaikuttavina tilanteina: "tarpeita nousee lisää", "pitää vaan osata joka alalla", "tilanteet vaikeutuu ja vaativuus kasvaa". Tilanteessa välittyy huoli osaamisen ja arjen hallinnan riittämättömyydestä: "ollaan hakoteillä [--]" Haastateltavien puheessa esiintyy runsaasti välttämättömyyttä ilmaisevia modaaliverbejä: 'täytyy', 'pitää' ja 'tarvitaan'.

Käytännön esimerkeillä osoitetaan tilanteen vakavuus: "[-- usein asiat kasautuu, ei saa tehtyä tehtäviä, ei ymmärretä suunnitelmia, turhaudutaan, tulee poissaoloja ja asiat mutkistuu”. Hanketoimijan tehtäväksi valitaan opettajan tai valmentajan rooli. Roolia kuvataan aktiivimuodossa ja paikoitellen imperatiivissa, jolloin toimijasta tulee myös vastuunkantaja: "Meidän pitää tunnistaa ja auttaa."

Aikuisten perustaidoiksi tai olennaisiksi taidoiksi haastatellut hanketoimijat nimeävät lukemisen ymmärtämisen taidot, tietotekniset taidot, maahanmuuttajien kielitaidot, ajanhallinnan ja arjenhallinnan taidot, kirjoittamisen ja kirjallisen esittämisen taidot, laskutaidot ja matemaattiset taidot, olennaisen hahmottamisen taidot ja oppimaan oppimisen taidot. PIAAC-tutkimuksen ja Taito-ohjelman kolmijakoon verrattuna taidot nähdään monimuotoisemmin. Taitojen heikkoudet kuvataan usein vyyhtinä erilaisia vaikeuksia, jotka saatetaan nimetä kattokäsitteillä oppimisvaikeus tai arjen hallinta.

Ratkaisut perustaitojen heikkouksiin syntyvät pedagogisen toimijan tulkintakehikossa. Näitä ovat kouluttajien ohjausosaamisen lisääminen, yhteisten aineiden integroiminen ammatillisiin opintoihin, taitotestit maahanmuuttajille ja oppimisvaikeuksien 
KoUlutuksen AMMATtilaisten TULKINTAKEHYS SIS ÄLTÄÄ RUNSAASTI HALLITSEVASTA RETORIIKASTA PUUTTUVIA

NÄKÖKULMIA.

ymmärtämisen lisääminen. Ratkaisut ovat yleensä Taito-ohjelman odotusten mukaisia: yhtäältä osallisuutta edistäviä, toisaalta spesifejä toimintamalleja perustaitojen kehittämiseksi.

Toimijoiden diskurssissa ei kuitenkaan välity ohjelmapuheen sisältämä globaalitalouden konteksti, vaan näkökulma on usein hyvinkin paikallinen ja yksilöllisiin tilanteisiin sitoutunut. OECD:n painottama inhimillisen pääoman diskurssi ei myöskään korostu hanketasolla, koska tavoitteet kuvataan enemmän yksilöllisistä tarpeista kumpuaviksi ja pikemminkin sosiaalista pääomaa tuottaviksi.

Toimijan vaikutusalueen ulkopuolella puhe muuttuu konditionaaliksi, joka ilmaisee epävarmuutta ja ehdollisuutta: "Opiskelijoille pitäis olla matalampi kynnys", "ytot [yhteiset aineet] pitäis integroida", " pitäis kehittää siten, et myös erilaiset oppijat pysyy mukana."

Hanketoimijat pyrkivät vaikuttavuuteen kertomalla kohderyhmiensä perustaidoista, mutta viestinnän dialogisuus toteutuu etupäässä muiden hanketoimijoiden verkostoissa, eikä keskustelua juuri käydä koulutuspolitiikasta vastaavien päättäjien kanssa. WPR-analyysin valossa hanketoimijoiden diskurssissa näkyvät makrotasolla tuotetun ongelman representaation vaikutukset. Koulutuksen ammattilaisen tulkintakehys kuitenkin laajentaa perustaitojen määrittelyä merkittävästi, jolloin diskurssi sisältää runsaasti hallitsevasta retoriikasta puuttuvia näkökulmia.

Tutkimuksen ryhmähaastatteluihin osallistuneet nuoret ja keski-ikäiset aikuisopiskelijat määrittelevät perustaidot omassa tulkintakehyksessään, jota he kuitenkin aktiivisesti peilaavat koko yhteiskunnan kontekstiin. PIAAC-tutkimuksen oletetun ongelman representaatio on mahdollisesti vaikuttanut haastateltujen näkemyksiin yhteiskunnan taitovaatimuksista koulutuksen ja median esittämien representaatioiden kautta, mutta WPR-analyysissa mikrotason diskurssi tarjoaa erityisesti puuttuvia näkökulmia.

Nuorten aikuisten määritelmässä korostuvat PIAAC-tutkimuksesta puuttuvat sosiaaliset ja itseilmaisun taidot: "---] et uskaltaa sanoa mielipiteensä [--] ja tulee toimeen kaikenlaisten ihmisten kanssa". Keskusteluun nousevat lisäksi kyseenalaistamisen ja tiedon jäsentelyn taidot: "on niin paljon tietoo, et pitää osata suodattaa sitä".

Uutta ammattia opiskeleville keski-ikäisille käytännön taidot ja ongelmatilanteiden ratkaisutaidot nousevat keskeisiksi, eivätkä he pidä kolmijakomallia riittävänä: "On tuo tosi suppee." Keskustelussa välittyy kokemuksen tuoma ymmärrys taitojen moniulotteisuudesta ja tilannesidonnaisuudesta. Luku- ja numerotaitoja sekä tietoteknisiä taitoja pidetään tarpeellisina mutta samalla osana yhteiskuntaa, jossa "monet asiat tulevat valmiina", ja ihmiset elävät toistensa avusta riippuvaisina. Keski-ikäisten keskustelijoiden mukaan monet ovat avuttomia kohdatessaan yksinkertaisia käytännön ongelmatilanteita, ja puheessa korostuu oman aktiivisuuden ja itsenäisen asioiden ratkaisukyvyn merkitys: "Ennen [töissä] perehdytettiin [--] ei enää oo aikaa [--] on vaan itse opittava."

Nuoret aikuiset mainitsevat perustaitoina tiedon jäsentelyn, mediakriittisyyden, kyseenalaistamisen, sosiaaliset taidot, monipuolisen itseilmaisun, oma-aloitteisuuden, kokonaisuuksien hallinnan ja aikatauluttamisen taidot. Tietotekniset taidot eivät nouse keskeisiksi, koska ne ymmärretään itsestään selvinä: "[--] ei selviä ilman [--] oletetaan et yhä nuoremmat osaa."

Keski-ikäisten aikuisopiskelijoiden diskurssissa esiintyvät kädentaidot ja käytännön taidot, vuorovaikutustaidot ja sosiaaliset taidot, ratkaisutaidot, tiedon hankkimisen ja soveltamisen taidot, luetun ymmärtämisen taidot, tietotekniset taidot, tilannetaju ja teknisten vikojen hahmottamisen taidot, priorisoinnin taidot, elämänhallinnan taidot ja oppimisen sekä pois oppimisen taidot

Keski-ikäisten puheessa yhdistyvät käytännön osaamisen ja tietotekniikan soveltamisen taidot: tietokoneitten kanssa täytyy osata alalla kuin alala [--] mutta tuntuu et menee vähän ylikin, ei haluta edes pyöränkumia vaihtaa [--] käytetään vaan puhelinta ja sovelluksia."

"On tietysti myös osattava hakea niitä sovelluksia [--] ja vaikka hakea se tieto vaikka YouTubesta se video miten pyöränkumi vaihdetaan”.

Keski-ikäiset kuvaavat tietotekniikan soveltamisen osin haasteelliseksi, kun taas nuorille sosiaaliset tilanteet voivat olla vaativampia:" [--] kun pystyy hoitaan kaikki netissä, niin on hankalaa kun joutuu soittaan ja siellä vastaa joku oikea ihminen."

Hanketoimijoiden diskurssiin verrattuna ymmärrys perustaidoista on samankaltainen, mutta sävyltään enemmän henkilöiden omaa vastuuta korostava. Ratkaisuja ei odoteta ulkopuolelta, mutta apua pitää osata myös pyytää. Taidot kuvataan ohjelmallista ja PIAAC-retoriikkaa laajemmin, ja ne kytkeytyvät koko arkielämän kontekstiin.

Arki näyttäytyy aikuisille henkilökohtaisen elämän kehyksissä, eikä yhteiskuntaa yleensä mielletä eikä tahdota mieltää kilpakenttänä, jossa on jatkuvasti pyrittävä maksimaaliseen suoritukseen (Rinne 2004, 240). Ohjelmalliseen ongelmanmäärittelyyn verrattuna kohderyhmät ja aikuiset omine tulkintakehyksineen konstruoivat ongelmia eri tavoin, jolloin heikon taitotason sijaan ongelmallisena koetaan esimerkiksi avuttomuus käytännön tilanteissa. Diskurssianalyysin valossa nämä eivät näyttäydy ristiriitaisina eivätkä toisiinsa törmäävinä tulkintoina, mutta ilman toimijatason ja kohderyhmien diskurssin huomioimista ymmärrys perustaidoista jää puutteelliseksi. WPR-analyysissa paikallistason diskurssi sisältää vaihtoehtoista ja osin PIAAC-tutkimuksen esitystä kyseenalaistavaa tietoa aikuisten perustaidoista

POHDINTA

Aikuisten kognitiivisista perustaidoista käydään keskustelua eri tulkintakehyksissä, mikä vaikuttaa siihen, mitä sanotaan, korostetaan ja jätetään pois tai miten uskomusjärjestelmää organisoidaan. Jos asioita tulkitaan vain omassa kehyksessä kuten usein tapahtuu, ymmärrys kaventuu.
Tutkimuksessani analysoidun kansallisen tason ohjelmallisessa diskurssissa, Taito-ohjelmassa, välittyy selvästi OECD:n ja Euroopan unionin määrittämä ymmärrys perustaidoista ja kehitystarpeista kilpailu- ja globaalitalouden kontekstissa. OECD:n teematutkimukset ovat luonnollisesti sen päätehtävän, kestävän talouskasvun turvaamisen, kehystämiä ja sitä edistäviä. Taloudellinen viitekehys huomioiden voidaan pohtia, miksi järjestön tuottama tulkinta on johtanut sen tiedolliseen auktoriteettiin esimerkiksi perustaitojen määrittelijänä. Tiedollista vahvuutta voidaan selittää sen käytössä olevalla rahoituksella, tieteellisillä voimavaroilla sekä hallinnollisten virkamiesten, poliitikkojen ja asiantuntijoiden tiiviillä yhteistyöllä. Kansallisella tasolla sen intressit sekä ohjauksellinen tiedonhallinta on syytä tiedostaa ja siksi tarkastella puhetta eri tulkintakehyksissä.

Kun perustaitoja koskevan diskurssin tasoja analysoidaan Bacchin WPR-menetelmällä, nähdään, että kansallisen Taito-ohjelman esittämä ongelman representaatio, merkittävä joukko aikuisia, joiden perustaidot ovat heikot, on muodostunut OECD:n tutkimuksissa ilman kansallisen tai paikallisen toimijatason vuorovaikutusta

OECD:n tulkinta kansalaisten perustaidoista ohjaa kansallisen koulutuspolitiikan retoriikkaa, mikä edelleen näyttää suuntaa koulutuksen toteuttajille. Diskurssianalyysin valossa PIAAC-tutkimuksessa luotu kolmijakomalli esittää perustaidot yksinkertaistetusti, eikä sen tarjoama inhimillisen pääoman käsite avaa tavoitteit riittävästi kaikkien osapuolten kannalta. Tulokset suosituksineen ikään kuin tarjoavat valtioille objektiivisen arvion kansalaisten perustaidoista globaalissa ympäristössä. Valittu valtadiskurssi vie huomion muilta aspekteilta, eikä muita näkökantoja esitetä.

Tutkimuksessani Taito-ohjelman rinnalla tarkasteltu aikuiskouluttajien tulkinta näkyy oppilaitoskontekstissa, mutta se ei ole vuoropuhelussa poliittisen tulkinnan kanssa. Aikuisopiskelijoiden sosiaalinen ja arjen tulkintakehys näkyy mikrotason diskurssissa joka välittyy hanketoimijoille, mutta ei ohjelmalliselle meso- tai makrotasolle. Ymmärryksen laajentamiseksi tarvitaan tulkintakehyksien risteämistä.

Aikuiskouluttajien ja kohderyhmien diskursseissa perustaitojen määritelmä syvenee ja monimuotoistuu Heidän puheessaan perustaidot määritellään laajast 


\author{
Lukutaito \\ Numerotaito \\ TVT-taidot \\ olennaisen hahmottamisen taidot \\ oppimaan oppimisen taidot tietotekniset taidot \\ lukemisen ymmärtämisen taidot \\ matemaattiset taidot arjenhallinnan taidot kielitaidot \\ ajanhallinnan taidot laskutaidot kirjoittamisen taidot \\ vuorovaikutus- ja sosiaaliset taidot käden ja käytännön taidot \\ oppimisen taidot kokonaisuuksien hallinta luetun ymmärtämisen taidot \\ mediakriittisyys aikatauluttaminen oma-aloitteisuus ratkaisutaidot \\ elämänhallinnan taidot sosiaaliset taidot hahmottamisen taidot \\ tietotekniset taidot tilannetaju tiedon hankkimisen taidot tiedon jäsentely \\ pois oppimisen taidot priorisoinnin taidot kyseenalaistaminen itseilmaisu
}

Kuvio 1. PIAAC-tutkimuksen määritelmä aikuisten perustaidoista monimuotoistuu paikallisten toimijoiden tulkintakehyksissä.

arjenhallinnan ja oppimisen taidoiksi sekä muun muassa lukemisen ymmärtämisen, kirjoittamisen, kielen, tietotekniikan, laskemisen ja olennaisen hahmottamisen taidoiksi.

Taitojen hallinta kytketään taloudellisen hyvinvoinnin lisäksi sosiaaliseen osallistumiseen, vastavuoroisuuteen ja oman elämän hallintaan, joita voi nimittää sosiaaliseksi ja kulttuuriseksi pääomaksi. Näitä ei mainita makrotason diskurssissa. Tulkintakehyksiä yhdistämällä myös hyvinvoinnin diskurssiin saadaan eri ulottuvuuksia, ja perustaitojen määrittelyn voi kategorisoida esimerkiksi kolmeen laajaan osa-alueeseen, johon konkreettiset taidot sisältyvät: 1) arjen hallinnan taidot, 2) ongelmanratkaisutaidot ja 3) tiedon hankkimisen ja tuottamisen taidot.

Analyysini antaa viitteitä siitä, että PIAAC-tutkimuksen perustaitoja koskeva diskurssi etenee diffuusio-mekanistisen viestinnän tyyppisesti: sanoma vastaanotetaan osaksi kansallista koulutuspolitiikkaa ja välitetään edelleen toimijatasolle, jolloin diskurssin tasot eivät kohtaa. Viestintä kulkee hierarkkisesti, sanomaa ylhälttä alas levittämällä, mikä on tyypillistä poliittisessa hallintokulttuurissa (Bacchi 2009; Servaes 2005).
Servaesin mukaan kansalaiset nähdään tällöin avun tarvitsijoina, ja kehitysprojektien toteuttamiseksi tarvitaan poliitikkojen ja asiantuntijoiden ohjausta.

Asetelma vaikuttaa toteutuneen myös perustaitojen kehittämisessä, vaikka esimerkiksi haastatellut toimijat osoittavat selvästi, että oma vastuu ja aktiivisuus ovat siinä tärkeitä. Jos tavoite on osallistuva ja toimiva kansalaisuus, viestintää pitäisi muuttaa yhteistoiminnallisen mallin suuntaan, jolloin kansalaiset nähdään kyvykkäinä, yhteistyökykyisinä ja itsenäisesti kehittyvinä. Mekanistinen malli on suoraviivaisuudessaan helpommin toteutettava ja tuloksia painottava kuin yhteistoiminnallinen malli, joka vaatii aikaa, resursseja ja kompromisseja.

Tutkimuksen keskeiset tulokset, PIAAC-tutkimuksen tarjoaman perustaitodiskurssin yksipuolisuus ja kansallisen ohjelmaretoriikan vastaanottava vaihtoehdottomuus, antavat aiheen ehdottaa nykyistä yhteistoiminnallisempaa perustaitojen määrittelyä ja kehittämistä erityisesti kansallisella tasolla. Yhteistoiminnallisessa viestintämallissa ongelmaa ei esitetä ulkopuolelta, ja poliitikkojen sekä asiantuntijoiden tarkoitus on tavoitella yhteistä näkemystä eri toimijoiden kanssa (Servaes 2005).
YHTEISTOIMINNALLISUUDESSA

YMMÄRRYS PERUSTAIDOISTA

MUODOSTUU TULKINTAKEHIKOITA

RISTEYTT ÄM ̈̈LL ̈̈.

Yhteistoiminnallisuudessa viestinnän ja puheen tasot kohtaavat horisontaalisesti, eivät ylhäälä alas osallistamalla. Perustaitojen kehittämisessä yhteistoiminnallisuus tarkoittaisi käytännössä osallistumista kaikilla diskurssin tasoilla - kansainvälisesti, kansallisesti ja paikallisesti - mutta mekanistiseen viestintämalliin verrattuna käänteisessä järjestyksessä. Perustaidot ja mahdollinen ongelma määritellään tällöin myös toiminnallisella ja kohderyhmien tasolla, jota poliittinen ohjelma ja tutkimus tukevat. Yhteistoiminnallisessa mallissa arvokkaaksi nousee ymmärrys perustaidoista ongelmineen myös niiden pedagogisten asiantuntijoiden ja aikuisopiskelijoiden tulkintakehikossa, joita asia koskettaa.

Perustaitoja koskevan diskurssin tarkastelu pakottaa pohtimaan, millaista todellisuutta diskurssi tuottaa, mitä se mahdollistaa ja mitä rajoittaa. OECD:n diskurssin vaikutus koulutuspolitiikkaan ja sen myötä sosiaaliseen todellisuuteemme on ilmeinen mutta yksipuolistava. Yksipuoliseen todellisuuden tulkintaan suostuminen edistää kapea-alaistavaa viestintäkulttuuria ja vaikuttaa siihen, mitä yhteiskunnassa arvostetaan. Joidenkin tutkijoiden mukaan esimerkiksi kansainväliset vertailututkimukset voivat lisätä yhteiskunnallista jakautumista asettamalla erilaiset taidot, kuten käytäntöön ja akateemiseen osaamiseen liittyvät taidot, eriarvoiseen asemaan (Tsatsaroni \& Evans 2013). Täm voi puolestaan johtaa koulutuspoliittiseen tempoiluun a suunnanmuutoksiin menestyksestä riippuen. Yksipuolistuneita tavoitteita pohtineiden tutkijoiden mukaan OECD on onnistuneesti yhdistänyt koulutusdiskurssin taloudellisiin tekijöihin ja siten luonut yleisen kysynnän koulutusuudistuksille (esim. Tröhler 2014; Hamilton \& Pitt 2011)

Inhimillisen pääoman tuottamista on markki noitu kuten elinikäistä oppimista, ikään kuin se olisi neutraali, kaikkien hyväksyttävissä oleva ja kaikkien etuja sellaisenaan ajava kehittämisperiaate (Tuomisto 2004). Samalla retoriikka legitimoi vallanpitäjien pyrkimyksiä sopeuttaa väestöä yritysten kilpailukyvyn ja tehokkuuden tarpeisiin (Griffin 1998,15). Siksi on hyödyllistä keskustella siitä, kenen ehdoilla koulutuksen tavoitteita luodaan ja mihin diskurssilla pyritään.

Perustaitojen suora kytkeminen taloudelliseen menestymiseen ja hyvinvointiin on saanut osakseen arvostelua, joka ei kuitenkaan juuri näy esimerkiksi mediassa käytävässä keskustelussa. Muutamat tutkijat ovat esittäneet kriittisiä arvioita perustaitojen liiallista korostamista ja koulutuksen mahdollistamien muiden tekijöiden huomioimatta jättämistä kohtaan. Perustaitojen kolmijako ja niiden mittaaminen kaikissa osallistujamaissa samoilla standardoiduilla välineillä voi johtaa osaamistavoitteiden yksipuolistumiseen.

PIAAC-tutkimuksen tarjoaman perustaitojen kolmijakomallin rinnalle ja mahdollisesti haastajaksi olisi hyödyllistä tuoda julki muita tutkimuksia ja määritelmiä aikuisten tarvitsemista perustaidoista erityisesti kansallisella ja paikallisella tasolla. Diskurssin eri tasojen tulkintakehikoiden havainnoiminen ja niiden aktiivisempi dialogisuus mahdollistaisi nykyistä moniulotteisemman ymmärryksen perustaidoista ja niiden kehittämisen tarpeista.

Tutkimuksessani diskurssin tasojen tarkastelu toi esiin vaihtoehtoisia ymmärtämisen tapoja, jotka eivät monesti kohtaa mekanistisessa viestinnässä. Yhteistoiminnallisessa aikuiskoulutuksen kehittämisen mallissa ne toimisivat toisiaan täydentäen. Poliittisella ohjelmalla on luotu tietty ymmärrys ongelmasta, mutta tulkintakehikoita risteyttämällä ymmärrys perustaidoista ja niiden kehittämisen tarpeista on merkittävästi laajempi.

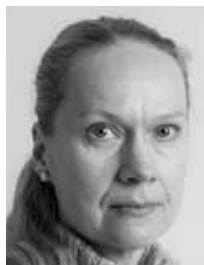

RIT MÄKINEN Vestintätieteiden tiedekunta Tampereen yliopisto 
'Käynnissä on tutkimuksen kolmas aalto, ja kokonaan uusi tutkimus on suunniteltu toteutettavaksi vuonn 2022. Aiemmat OECD.n kansainvaliset aikuisten lukutaidon ja perustaitojen tutkimukset toteutettiin vuosina 1997-2000 ja 2002-2006.

\section{LÄHTEET.}

Antikainen, A. (2006). Koulutuksen globaali ja paikallinen merkitys. Aikuiskasvatus 26 (2).

Bacchi, C. (2009). Analysing Policy: What's the problem represented to be? Australia: Pearson Australia.

Bacchi, C. (2012). Introducing the 'What's the Problem Represented to be?' approach. Teoksessa Bletsas, A. \& Bearsley, C. (toim.). Engaging with Carol Bacchi: Strategic Interventions \& Enchanges. Adelaide: University of Adelaide Press.

Cort, P. \& Larson, A. (2015). The non-shock of PIAAC - Tracing the discoursive effects of PIAAC in Denmark. European Educational Research Journal 14 (6). 531-548.

Delanty, G. (2000). Citizenship in a Global Age. Society, Culture, Politics. Buckingham: Open University Press. van Dijk, T. (1993). Principles of critical discourse analysis. Discourse \& Society 4 (2), 249-283.

Edwards, R. (2010). Mobilizing lifelong learning: governmentality in educational practices. Journal of Education Policy 17 (3), 353-365.

Entman, R. (1993). Framing: Toward Clarification of a Fractured Paradigm. Journal of Communication 43 (4), 51-58.

European Parliament (2000). Conclusions on the Lisbon Strategy 2000. www.europarl.europa.eu/summits/ lis1_en.htm (17.11.2017).

Grek, S. (2009). Governing by numbers: the PISA 'effect' in Europe. Journal of Education Policy 24 (1), 23-37.

Griffin, C. (1998) Public rhetoric and public policy: analysis the difference for lifelong learning. Teoksessa Perspectives on Li
Page Limited.

Hamilton, M. (2016). Imaging Literacy. A Sociomaterial Approach. Teoksessa Yasukawa, K. \& Black, S. (toim.) Beyond Economic Interests. Critical Perspectives in Adult Literacy and Numeracy in a Globalised Wo Rotterdam. The Netherlands: Sense Publishers.

Hamilton, M. \& Pitt, K. (2011). Changing policy discourses: Constructing literacy inequalities. Internationa Journal of Educational Development 31, 596-605.
OECD (1998). Human Capital Investment: An Internatioof Adult Skills: Finland. Preliminary version. Paris:

okinen, A. (2002). Vakuuttelevan ja suostuttelevan reto kan analysoiminen. Teoksessa Jokinen, A. \& Juhila K. \& Suoninen, E. Diskurssianalyysi lilikkeessa. 2. painos. Tampere: Vastapaino, 126-160.

Juhila, K. (2002). Kulttuurin jatkuvasti rakentuvat kehät. Tilanteisesta kulttuuriseen kontekstiin. Teoksessa Jokinen, A. \& Juhila, K. \& Suoninen, E. Diskurssianalyysi liikkeessä. 2. painos. Tampere: Vastapaino.

Karvonen, E. (2000). Tulkintakehys (frame) ja kehystäminen. Tiedotustutkimus 23, 78-84.

Kivinen, O. \& Hedman, J. \& Nurmi, J. (2016). Suomalaisaikuisten osaaminen väitettyä parempaa. Janus 24 (2),

Kopecký, M. (2011). Foucault, Governmentality, Neoliberalism and Adult Education - Perspective on the Normalization of Social Risks. Journal of Pedagogy 2 (2), 246-262.

Kupiainen, R. (2006). Yhteistoiminnallinen medialukutaito. Aikuiskasvatus 26 (3), 182-188.

Lester, J. \& Lochmiller, C. \& Gabriel, R. (2016). Locating and Applying Critical Discourse Analysis within Education Policy: An Introduction. Education Policy Analysis Archives 24 (102), 1-11.

Lyly-Yrjänäinen, M. \& Haltia, P. \& Packalen, P. (2015) Osaamisen ja elinikäisen oppimisen Suomi - Riittävätkö kaikkien perustaidot? Työpoliittinen aikakauskirja 3, 5-17.

Mahon, R. \& McBride, S. (2009). The OECD and Transnational Governance. Vancouver: UBC Press.

Malin, A., Sulkunen, S. \& Laine, K. (2013). Kansainvälisen aikuistutkimuksen ensituloksia. PIAAC 2012. Opetus-ja klttuuriministeriön julkaisuja 2013:19.

Morgan, C. \& Volante, L. (2016). A review of the Organisation for Economic Cooperation and Development's capital discolcation surveys. Governance, human Education 14 (6), 775-792.

Musset, P. (2015). Building Skills For All: A Review of Finland. Policy insights on literacy, numeracy and digital skills from the survey of adult skills. OECD Skills Studies. OECD 2015: http://www.oecd.org/ finland/Building-Skills-For-All-A-Review-of-Finland.pd (15.11.2017) practices. New York: Peter Lang Publishing, 91-117. nal Comparison. Paris: OECD Publishing.

OECD (2012) Literacy, Numeracy and Problem Solving in Technology-Rich Environments - Framework for the OECD Survey of Adult Skills. OECD Publishing: http://www.oecd.org/skills/piaac/PIAAC\%20Framework\%202012--\%20Revised\%2028oct2013_ebook. pdf (luettu 5.11. 2017).

OECD (2013). The Survey of Adult Skills. Reader's Companion. Paris: OECD Publishing.

OECD (2015). OECD Skills Studies. Data Policy Reviews OECD Publishing.

Servaes, J. (1999). Communication for Development. One World, Multiple Cultures. New Jersey: Hampton Press.

Servaes, J. \& Malikhao, P. (2005). Participatory communication: the new paradigm? Teoksessa Hemer \& Tufte (toim.) Media \& Glocal Change: Rethinking Communication for Development. Buenos Aires: CLASCO, 91-103.

Slee, R. \& Stambach, A. (2010). Globalizing education policy. British Journal of Sociology of Education 31 (3), 353-358.

Tsatsaroni, A. \& Evans, J. (2013). Adult numeracy and the totally pedagogised society: PIAAC and other international surveys in the context of global educational policy on lifelong learning. Educational Studies in Mathematics 87 (2), 167-186.

. Kestaváa kasvua ja työta 2014-2020. Suomen rakennerahasto-ohjelma. Euroopan sosiaalirahaston valtakunnallisten teemojen toteutussuunnitelma. Toimintalinja 4: Koulutus, ammattitaito ja elinikäinen oppiminen: http://minedu.fi/documents/1410845/4046235/Rakennerahastot+ohjelman toimintalinja+4/cb941011-27a8-4487-be86-0c7e717c3c2d (3.10.2017). Opetus- ja kulttuuriministeriö.

Rantala, L. \& Suoranta, J. (2008). Digital Literacy Policies in the EU - Inclusive Partnership as the Final Stage of Governmentality? Teoksessa Lankshear, C. \& Knobel, M. (toim.) Digital Literacies: Concepts, policies and

Rinne, R. (2004). Elinikäisen oppimisen retoriikka ja koulutuspolitiikka. Teoksessa Sallila, P. (toim.) Elämänlaajuinen oppiminen ja aikuiskasvatus. Aikuiskasvatuksen 44. vuosikirja. Helsinki: Kansanvalistusseura, 219-247.

Rinne, R. \& Kallo, J. \& Hokka, S. (2004). Too Eager to Comply? OECD Education Policies and the Finnish Response. European Educational Research Journal 3 (2). http://journals.sagepub.com/doi/pdf/10.2304/ eerj.2004.3.2.3 (15.10. 2018)
Tuomisto, P. (2004). Elinikäisen oppimisen toinen sukupolvi - unohtuiko jotain? Teoksessa Sallila, P. (toim.) Elämänlaajuinen oppiminen ja aikuiskasvatus. Aikuiskasvatuksen 44. vuosikirja. Helsinki: Kansanvalistusseura, 49-84.

Tröhler, D. (2014). Change management in the governance of schooling: The rise of expert planners and statistics in
$116,1-26$.

Windemeersch, D. \& Olesen, H. (2012). Editorial: The Effects of policies for the education and learning of adults - from 'adult education'to 'lifelong learning', from 'emancipation'to 'empowerment'. European Journal for Research on the Education and Learning of Adults 3 (2), 97-101.

Yasukawa, K. \& Black, S. (toim.) (2016). Introduction. Beyond Economic Interests. Critical Perspectives in Rotterdam: Sense Publisher Adult Literacy and Numeracy in a Globalised World. 